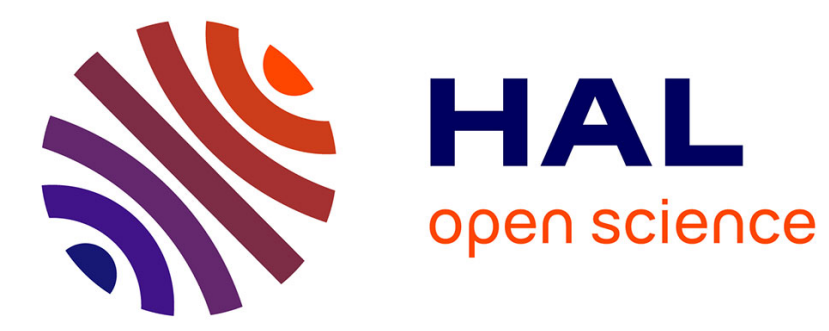

\title{
Network Form and Performance. The Case of Multi-Unit Franchising
}

Muriel Fadairo, Cintya Lanchimba, Josef Windsperger

\section{To cite this version:}

Muriel Fadairo, Cintya Lanchimba, Josef Windsperger. Network Form and Performance. The Case of Multi-Unit Franchising. 2015. halshs-01128075

\section{HAL Id: halshs-01128075 https://shs.hal.science/halshs-01128075}

Preprint submitted on 9 Mar 2015

HAL is a multi-disciplinary open access archive for the deposit and dissemination of scientific research documents, whether they are published or not. The documents may come from teaching and research institutions in France or abroad, or from public or private research centers.
L'archive ouverte pluridisciplinaire HAL, est destinée au dépôt et à la diffusion de documents scientifiques de niveau recherche, publiés ou non, émanant des établissements d'enseignement et de recherche français ou étrangers, des laboratoires publics ou privés. 
UMR 5824

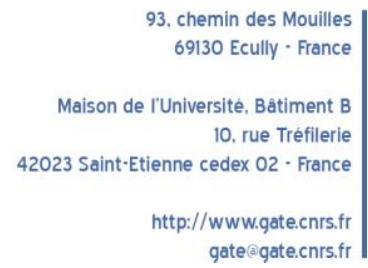

WP 1502 - March 2015

Network Form and Performance

The Case of Multi-Unit Franchising

\author{
Muriel Fadairo \\ Cintya Lanchimba \\ Josef Windsperger
}

\begin{abstract}
:
Multi-unit franchising (MUF) is a governance form inside franchising networks where the franchisor transfers to the franchisees the right to own and operate more than one outlet. While previous empirical literature has revealed various advantages of MUF as compared to single-unit franchising (SUF), we study the impact of this governance form on the network performance, taking into account different contexts. Our results from propensity score matching show that MUF leads to higher performance. However, non-parametric estimations highlight thresholds suggesting that a mix of SUF and MUF is a more efficient governance form than a pure MUF network.
\end{abstract}

Keywords:

Network governance, franchising, propensity score matching, nonparametric regressions.

JEL codes:

M21; L14; C14

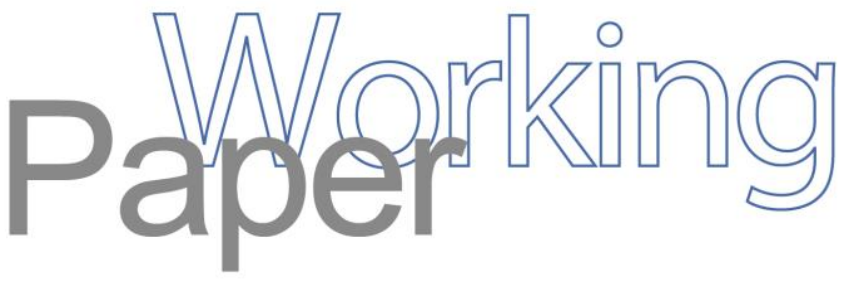




\title{
Network Form and Performance The Case of Multi-Unit Franchising
}

\author{
MURIEL FADAIRO \\ Université de Lyon, Lyon, F-69007, France \\ CNRS, GATE Lyon Saint-Etienne, Ecully, F-69130, France \\ Université Jean Monnet, Saint-Etienne, F-42000, France \\ muriel.fadairo@univ-st-etienne.fr \\ CINTYA LANCHIMBA \\ National Polytechnic School of Quito, Ecuador \\ \& \\ Université de Lyon, Lyon, F-69007, France \\ CNRS, GATE Lyon Saint-Etienne, Ecully, F-69130, France \\ Université Jean Monnet, Saint-Etienne, F-42000, France \\ cintya.lanchimba@univ-st-etienne.fr
}

JOSEF WINDSPERGER

University of Vienna, Austria

Faculty of Business, Economics and Statistics

Oskar-Morgenstern-Platz 1, 1090 Vienna

josef.windsperger@univie.ac.at

The authors gratefully acknowledge financial support from the National Secretary of Higher Education, Science,Technology and Innovation of Ecuador (SENESCYT). We thank Richard Baron, Marko Grünhagen, Thierry Pénard, and Rozenn Perrigot for helpful comments and suggestions. The usual caveat applies. 
Abstract. Multi-unit franchising (MUF) is a governance form inside franchising networks where the franchisor transfers to the franchisees the right to own and operate more than one outlet. While previous empirical literature has revealed various advantages of MUF as compared to single-unit franchising (SUF), we study the impact of this governance form on the network performance, taking into account different contexts. Our results from propensity score matching show that MUF leads to higher performance. However, non-parametric estimations highlight thresholds suggesting that a mix of SUF and MUF is a more efficient governance form than a pure MUF network.

\section{Keywords:}

Network governance, franchising, propensity score matching, nonparametric regressions.

JEL codes: M21; L14; C14. 


\section{Introduction}

The aim of this paper is to study the impact of multi-unit franchising (MUF) on the network performance. MUF is a governance mode where the franchisor transfers to the franchisee the right to own and operate more than one outlet. Two types of multi-unit franchising are distinguished: area development franchising and sequential multi-unit franchising (Kaufmann and Dant, 1996; Grünhagen and Mittelstaedt, 2005). Area development franchising is based on a contract that allows a franchisee to run several outlets at a certain time in a specified geographical area. It is often associated with a territorial exclusivity right. Sequential multi-unit franchising refers to a contract that transfers to the franchisee the right to open a new unit in addition to the existing one.

Previous empirical studies regarding this network form are based on different theoretical frameworks, such as resource scarcity theory (Kaufmann and Dant, 1996; Weaven and Frazer, 2003; Grünhagen and Mittelstaedt, 2005), dependence theory (Dant and Gundlach, 1998; Grünhagen and Mittelstaedt, 2002; Dant et al., 2011), transaction costs theory (Kaufmann and Kim, 1995; Weaven and Frazer, 2003; Hussain et al., 2013), property rights theory (Hussain and Windsperger, 2013), agency theory (Kaufmann and Dant, 1996; Dant and Nasr, 1998; Weaven and Frazer, 2003; Kalnins and Lafontaine, 2004; Grünhagen and Mittelstaedt, 2005; Garg et al., 2005; Sanchez-Gomez et al., 2010; Gillis et al., 2011; Jindal, 2011), and organizational capability theory (Hussain and Windsperger, 2015).

The empirical literature reveals various advantages of MUF as a network form compared to single-unit franchising (SUF). Sequential MUF is considered to be a means to reward high quality franchisees and thereby to improve the system efficiency (Sanchez-Gomez et al., 2010). A complementary argument is that, since existing franchisees are familiar with the franchisor's business format and with the local market conditions, MUF reduces the risk of failure (Bates, 1998) and enables the franchisor to avoid incurring additional costs for 
screening, recruiting, and training (Kaufmann and Dant, 1996). In addition, multi-unit franchisees usually have higher administrative capabilities than single-unit franchisees (Grünhagen and Mittelstaedt, 2005). MUF favors system uniformity (Weaven and Frazer, 2007), economies of scale for the franchisor and the franchisee (Grünhagen and Mittelstaedt, 2002), and a lower level of conflict between the two of them due to the smaller number of franchisees that need to be coordinated (Zellner et al., 1980; Weaven and Frazer, 2004). Based on these results, it is expected that MUF positively impacts the performance of franchise networks.

Although previous research has highlighted a positive influence of MUF on the system performance (e.g. system growth) (Kaufmann and Kim, 1995; Kaufmann and Dant, 1996), Grünhagen and Mittelstaedt, 2002), no previous study has provided an explanation and empirical tests of the major determinants of the MUF network performance. Starting from this gap, the aim of this study is to develop and test hypotheses based on organizational economics theories (agency theory, transaction cost theory, and property rights theory) and the relational governance view to explain the performance of MUF networks. Overall the results of the empirical analysis derived from the German and Swiss franchise data provide some support of our research model.

The paper proceeds as follows. Section 2 develops the hypotheses. Empirical specifications are provided in Section 3. Section 4 contains a first set of estimations. Dealing with the impact of MUF on the performance, we address firstly the potential selection and endogeneity bias relating to the use of an organizational choice (MUF) as an explanatory variable. Section 5 presents our core results, which are based on additive nonparametric regressions. We study the effect of MUF on the network performance, distinguishing different contexts. Section 6 draws conclusions. 


\section{Analytical Framework and Hypotheses}

In the following, we develop a multi-theoretical framework based on organizational economics theories (agency theory, transaction cost theory, and property rights theory) and the relational governance view to explain the performance of MUF networks.

\subsection{MUF and Relationship Hazards}

Agency theory emphasizes the emergence of opportunistic behavior under asymmetric information. In franchising, Rubin (1978) as well as Mathewson and Winter (1985) are important starting points of a vast literature on franchising in the framework of agency theory (e.g., Brickley, 1999; Mazzeo, 2004; Lafontaine and Oxley, 2004; Gonzalez-Diaz and Solis-Rodriguez, 2012; Barthélemy 2008, 2011). In the franchise relationship, opportunistic behavior may arise due to asymmetric information in favor of the franchisee regarding his/her level of effort (moral hazard) or his/her type (adverse selection). In addition, as the franchise network is based on a common brand name and reputation, each franchisee can free ride. Thus, agency costs in franchising result from behavioral uncertainty due to free riding on the common brand name and the shirking behavior of the network partners.

MUF offers a solution to this relationship hazards. Under MUF, the agency problem is transferred to the downstream level by establishing mini-chains in which the franchisees are in charge of the outlet managers. Studying the factors that influence the choice of the organizational form when franchisors add new franchised units to their networks, Sanchez-Gomez et al. (2010) provide evidence from the Spanish franchise sector that MUF mitigates free riding and adverse selection problems. In addition, based on longitudinal North American data, Jindal (2011) shows that by reducing the size of the internal hierarchy, MUF reduces moral hazard problems. Gillis et al. (2011) obtain similar results on US data regarding restaurant franchisors. They show that faster-growing franchisors use MUF as a reward in a tournament to reduce agency problems. From this agency-theoretical perspective we can 
derive the following hypotheses:

\section{Hypothesis 1}

Brand name value is positively associated with the performance of MUF networks.

\section{Hypothesis 2}

Behavioral uncertainty due to shirking is positively associated with the performance of MUF networks.

\subsection{MUF and Environmental Hazards}

According to the transaction cost theory, environmental uncertainty influences the choice of inter-organizational governance mechanism (Williamson, 1975, 1991). In the case of franchising, environmental uncertainty reflects the difficulty faced by the franchisor in predicting the development of the local market due to economic hazards (e.g., demand and competition) and institutional changes. Williamson (1991) and Gibbons (2005) show that a high level of environmental uncertainty requires the firm to be more adaptable by delegating some coordination tasks to local entrepreneurs. Applied to franchising, this reasoning justifies the use of more SUF assuming that single-unit franchisees have a stronger entrepreneurial orientation compared to the outlet managers in a mini-chain and react more quickly to the changes in local markets (Sorenson and Sorensen, 2001). Therefore, with a high level of environmental uncertainty, SUF would provide performance advantages compared to MUF due to the single-unit franchisees' higher level of entrepreneurial capabilities and incentives to exploit the local market opportunities (Garg et al., 2005). We formulate the following hypothesis:

\section{Hypothesis 3}

Environmental uncertainty is negatively associated with the performance of MUF networks. 


\subsection{MUF and Intangible System-specific Assets}

According to the property rights reasoning (Hart 1995), intangible system-specific assets influence the structure of ownership rights in franchising network (e.g., Windsperger, 2004a; Windsperger and Dant, 2006). Franchisor's system-specific assets includes his/her business know-how, skills in site selection, product development, marketing advertising, purchasing and merchandizing. When the system-specific assets are characterized by a high degree of intangibility, they generate a high residual income stream. In this case, franchisors will exersise more control over their use at the local market (Hussain and Windsperger 2013) by setting up MUF agreements. MUF enables the franchisors to apply more standardized operational routines and procedures, resulting in performance advantages. Hence, we formulate the following hypothesis:

\section{Hypothesis 4}

Intangible system-specific assets are positively associated with the performance of MUF networks.

\subsection{MUF and Trust}

In recent years, several studies have investigated the role of trust in franchising (e.g., Cochet et al., 2008 ; Dickey et al., 2008; Croonen, 2008; Dant et al., 2011; Davies et al., 2011 ; Gorovaia and Windsperger, 2013; Mumdziev and Windsperger, 2013). According to the relational governance view (e.g., Macneil 1983; Heide and John 1992; Zajac and Olsen, 1993; Dyer and Singh 1998; Poppo and Zenger, 2002; Gulati and Nickerson, 2008), trust is an important informal governance variable that may mitigate the problem of contractual incompleteness due to uncertainty and intangibility. In a recent study, Griessmair et al. (2014) highlight the impact of trust on the franchisor's organizational choice regarding MUF. 
Applying the relational governance reasoning, we expect that a high level of trust between the franchisor and the franchisees will improve the performance of MUF networks by reducing transaction costs, due to lower relational risk, and increasing transaction value, due to more information sharing. Hence, we formulate the following hypothesis:

\section{Hypothesis 5}

Trust is positively associated with the performance of MUF networks.

\subsection{MUF and Decision Rights}

Already Fama and Jensen (1983) argued that the decision structure of a firm consists of two interrelated parts: decision managment rights and decision control rights. Applied to franchising networks, under MUF the franchisor transfers a higher fraction of decision management rights to the local franchisees than under SUF. Specifically, the multi-unit franchisees have more decision making power regarding monitoring, local human resource management and knowledge transfer between the headquarters and the local outlets (Windsperger, 2013). Consequently, we expect that complementarity between MUF and the delegation of decision rights to multi-unit franchisees will increase the performance of MUF networks. Hence, we formulate the following hypothesis:

\section{Hypothesis 6}

Delegation of decision rights is positively associated with the performance of MUF networks. 
Overall, we can conclude that brand name, behavioral uncertainty, environmental uncertainty, system-specific knowhow, trust and decision rights influence the performance of MUF networks: Figure 1 provides an overview of the research model.

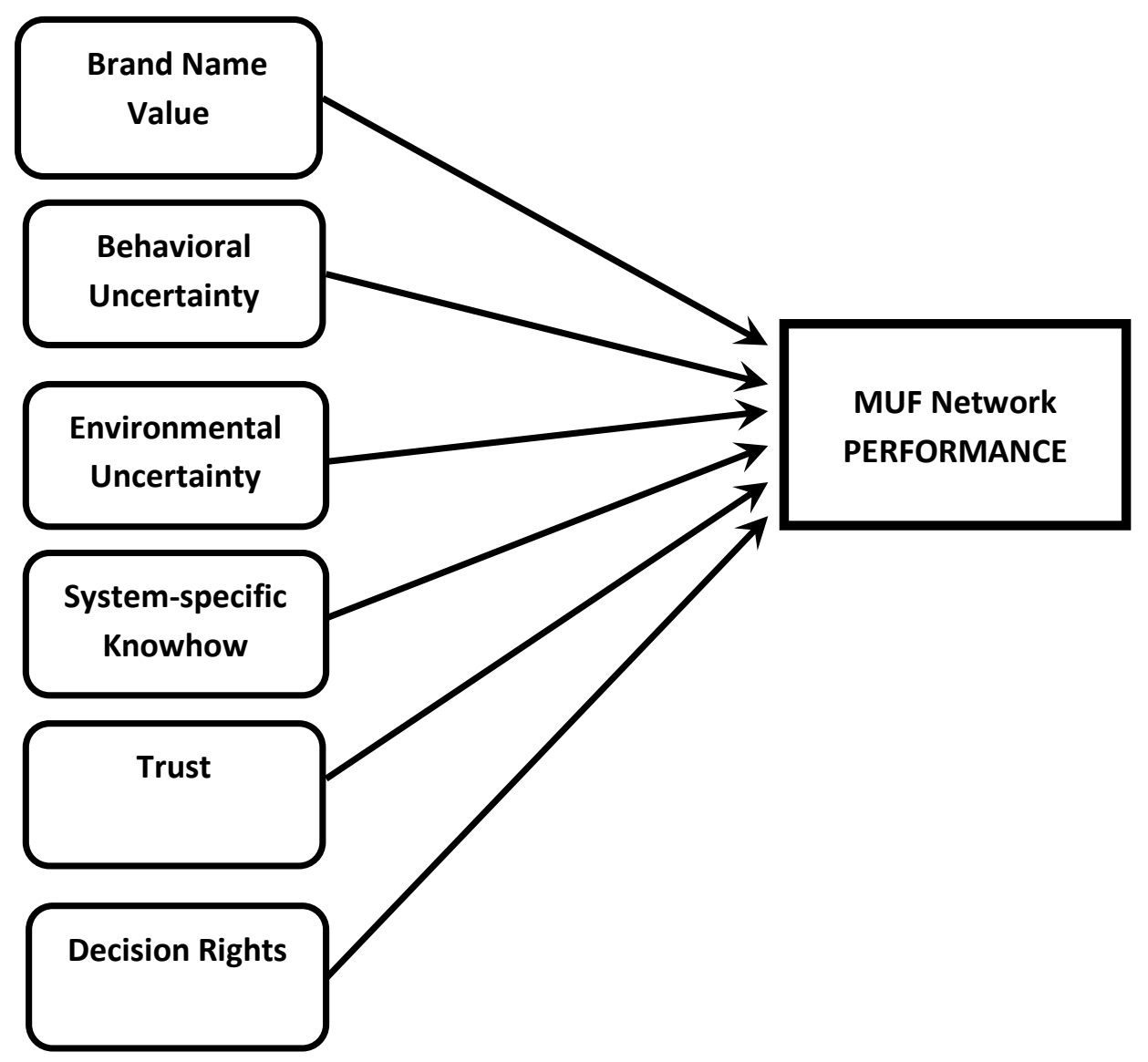

FIGURE 1. ANALYTICAL FRAMEWORK 


\section{Data and measurement}

\subsection{Data collection}

We use German and Swiss data to test the research model on performance of MUF networks (see figure 1). The directories of the German and Swiss franchise associations and "Franchise Wirtschaft" (a Bond's Franchise Guide type directory of all franchise systems in Austria, Germany, and Switzerland) list all franchise systems operating in these countries. Various demographic data (i.e., the year the system was established, the number of outlets, the business sector, etc.) are also listed regarding each system in the Franchise Wirtschaft. Judgmental sampling was employed and the sample regroups franchised networks with at least five outlets. The final sample consists of 491 German and 176 Swiss franchise systems.

The data were collected via self-administered questionnaires developed in several steps. After several preliminary refinements, in-depth interviews were conducted with franchise professionals from the Austrian and German franchise associations and a pre-test was conducted with 20 franchisors in Austria. The respondents are selected based on their expertise and relevance to the subject under investigation. This demonstrates the use of the key informant (McKendall and Wagner III, 1997) approach for data collection. Accordingly, the key informants for this study were senior managers who are mainly responsible for the expansion of their franchises. The information about the key informants was retrieved from the Franchise Wirtschaft. The questionnaires were mailed to the key informants of all of the 491 relevant franchise systems in Germany and 176 in Switzerland. A total number of 166 questionnaires were completed. The response rate is $27.9 \%$ for Germany and $17.05 \%$ for Switzerland.

Two methods were used to check for non-response bias. First, the non-response bias was estimated by comparing early versus late respondents (Armstrong and Overton, 1977), where 
late respondents serve as proxies for non-respondents. Second, the respondents were compared to non-respondents in terms of age, size, advertising fee, and royalties to determine whether non-response was a serious problem for the data. These variables are available in the 'Franchise Wirtschaft' for the listed systems. These data were used to run independent sample t-tests in order to check whether the sample is representative. The results show that there is no significant difference between the respondents and the non-respondents. In addition, on the basis of Podsakoff et al. (2003), the Harman's single factor test was used to examine whether a significant amount of common method variance exists. After conducting factor analysis, it was possible to feel confident that common method bias is not a serious problem in this study.

\subsection{Measurement}

3.2.1 Dependent variable. The dependent variable is the performance of the franchising network evaluated by the franchisor. We used subjective measures of franchisor performance. According to previous studies (e.g. Dess and Robinson, 1984; Glaister and Buckley, 1998), subjective performance measures are highly correlated with objective performance measures. The franchisors were asked to rate their network performance on a seven-point Likert scale. Thus, the performance is measured as the sum of the following items: Savings in administrative costs, system growth, better alignment of products and services to the customer need, more effective coordination between the head office and outlets, reduction in costs, increase in yields, increase in innovation, savings in coordination and control costs, better quality of offered products, profit growth (Cronbach alpha $\alpha=$ $0.849)$. 
3.2.2 Independent variables. MUF: Two measures of MUF are successively used. First, a dummy variable indicating the presence of MUF in the network, then, a quantitative variable expressing the percentage of MUF (ratio between the number of franchised units divided by the numer of franchisees). A similar ratio has been used in previous studies as an indicator for MUF (Gomez et al., 2010; Griessmair et al., 2014). .

Brand name (Free-riding risk): Based on the works of Combs et al. (2004) and Barthélemy (2008), the brand name is measured on a seven-point Likert scale. The franchisors were asked to rate their network on brand name strength compared with competitors, brand recognition compared with competitors, reputation for quality, and the importance of the brand name for achieving competitive advantage $(\alpha=0.803)$.

Environmental uncertainty: Based on Celly and Frazier (1996) and John and Weitz (1989), the franchisors were asked to rate fluctuations in outlet sales, the changes of the market environment, and the difficulty to predict the development at the local market on a seven-point Likert scale $(\alpha=0.845)$.

Behavioural uncertainty: Adapted from Anderson (1985) and Mumdziev and Windsperger (2013), the franchisors were asked to rate the difficulty of measuring the outlet performance (the franchisee or manager), controlling their behavior, and assessing their competencies and capabilities on a seven-point Likert scale $(\alpha=0.768)$.

System-specific knowhow: Consistent with Erramilli et al. (2002), this variable measures the difficulties of transferring the system knowledge from the franchisor to the franchisees. The franchisors were asked to rate the transfer of brand name, marketing knowhow, organizational knowhow, quality management, accounting, human resources know-how to franchisees on a seven-point Likert scale $(\alpha=0.915)$.

Trust: In line with the works of Anderson and Narus (1990) and Dyer and Chu (2000), 
the franchisors were asked to rate the level of trust between themselves and their franchisees, the atmosphere of openness and sincerity, and the degree of mutual cooperation $(\alpha=0.803)$.

Decision rights: The decision rights index (as formative construct) is based on Windsperger (2004b) and Mumdziev and Windsperger (2011). The franchisors were asked to rate the franchisee's influence on operational decisions in the franchising network regarding procurement, price and product/service, advertising, human resources (recruitment and training), investment and finance, outlet equipment, introduction of new products, and the application of accounting systems on a seven-point Likert scale.

\subsubsection{Control variables}

Size is measured as the total number of company-owned and franchised outlets in the network.

Age is measured by the number of years since the first franchise outlet was established.

Advertising rate are measured as the percentage of the franchised unit's sales.

Advantages of franchising: The franchisors were asked to rate the advantages of franchising compared to company-owned outlets in respect of quality control, innovation, local market knowledge, administrative skills, and human resource management on a seven-point Likert scale $(\alpha=0.788)$.

Franchisor's transaction-specific investments: The franchisors were asked to rate their initial investment with regard to their expenses for their franchisees' training at the beginning of the contract, and their expenses for the provision of technical support to the franchisee at the beginning of the relationship on a seven-point Likert scale $(\alpha=0.722)$ 


\subsection{Summary statistics and correlations}

Table 1 reports the means, standard deviation and correlations between the dependent, independent and control variables. Because the presence of a few missing values may bias the estimations $^{1}$, we choose to impute them using the multiple imputation method ${ }^{2}$. Descriptive statistics regarding the variable MUF show that 106 of the sample networks (versus 60) use this organizational form. ANOVA analysis underlines the relevance of examining the link between MUF and the network performance. The analysis highlights the statistically significant difference in the mean performance of the two types of organizational forms; that is, MUF networks compared to SUF networks $(F=12.652, \quad p-$ value $=0)$.

\footnotetext{
${ }^{1}$ The missing values vary between $0.6 \%$ and $15.6 \%$. The lower bound relates to several components of the brand name, trust, and performance variables; the upper bound relates to components of the decision rights variable.

2 The statistical theory suggests that using the method of averages to complete the missing data introduces bias in the value of the estimator and its variance. Rubin (1996) proposes multiple imputation as a solution. This method uses Monte Carlo simulations to replace the missing data from a number $(\mathrm{m}>1)$ of simulations. In each simulation, the complete data matrix is analysed using conventional statistical methods. Finally, the method combines the results to generate robust estimators. Thus, the multiple imputation method replaces missing values at random, and does not generate bias in the allocation of imputed values.
} 
Table 1

\section{Summary statistics}

\begin{tabular}{|c|c|c|c|c|c|c|c|c|c|c|c|c|c|c|c|}
\hline & Mean & $\mathrm{SD}$ & 1 & 2 & 3 & 4 & 5 & 6 & 7 & 8 & 9 & 10 & 11 & 12 & 13 \\
\hline 1. Performance & 35,5177 & 7,36157 & 1 & & & & & & & & & & & & \\
\hline 2. $\operatorname{MUF}(\ \%)$ & ,4765 & ,92669 &, $311^{* *}$ & 1 & & & & & & & & & & & \\
\hline $\begin{array}{l}\text { 3. Environmental } \\
\text { uncertainty }\end{array}$ & 7,6329 & 3,32415 &,$- 228^{* *}$ &,$- 270^{* *}$ & 1 & & & & & & & & & & \\
\hline 4. Decision rights & 58,8609 & 14,22159 &, $446^{* *}$ &, $205^{* *}$ &, 012 & 1 & & & & & & & & & \\
\hline $\begin{array}{l}\text { 5. System } \\
\text { know-how }\end{array}$ & 29,1220 & 10,47697 &, $402^{* *}$ &, $261^{* *}$ &,- 011 &, $226^{* *}$ & 1 & & & & & & & & \\
\hline 6. Brand name & 22,5663 & 4,41263 &, $376^{* *}$ &, $187^{*}$ &,- 055 &, $188^{*}$ &, 112 & 1 & & & & & & & \\
\hline 7. Trust & 13,3734 & 4,01929 &,- 024 &,- 079 &, $157^{*}$ &, 015 &,$- 286^{* *}$ &, 080 & 1 & & & & & & \\
\hline $\begin{array}{l}\text { 8. Behavioral } \\
\text { uncertainty }\end{array}$ & 6,5489 & 2,89779 &, $283^{* *}$ &, $268^{* *}$ &,- 011 &, $251^{* *}$ &, $371^{* *}$ &, $157^{*}$ &,$- 235^{* *}$ & 1 & & & & & \\
\hline 9. Advertising rate & 1,1584 & 3,57935 &, 051 &, 033 &,- 064 &,- 070 &,- 083 &, $176^{*}$ &,- 063 &, 001 & 1 & & & & \\
\hline $\begin{array}{r}\text { 10. Franchisor } \\
\text { investment }\end{array}$ & 13,0602 & 3,88735 &, $198^{*}$ & ,143 &,- 013 &, 007 &, $211^{* *}$ &, $159^{*}$ &, 057 &,- 064 &, 092 & 1 & & & \\
\hline 11. Network age & 11,3081 & 7,97799 &, 123 &, $196^{*}$ & ,015 &, 026 & ,103 & , 106 &,- 033 &, $162^{*}$ &, 030 &,- 052 & 1 & & \\
\hline 12. Size & 137,1080 & 282,98744 & 069 &, 085 & ,001 &, $164^{*}$ &,- 021 &,- 144 &, 033 & 059 &,- 020 &,- 119 &, $390^{* *}$ & 1 & \\
\hline $\begin{array}{l}\text { 13. Franchise } \\
\text { advantage }\end{array}$ & 17,7496 & 6,11307 &,- 079 &,$- 172^{*}$ & 145 & ,015 & ,108 &,- 032 &, $266^{* *}$ & 027 &,- 135 & ,041 &,- 088 &,- 023 & 1 \\
\hline
\end{tabular}

Note: * Signifiant at the $10 \%$ level, $* *$ at the $5 \%$ level, *** at the $1 \%$ level. 


\section{Control for potential selection bias}

\subsection{Methodology}

4.1.1 Heckman method. The choice to use MUF as an organizational form is a strategic decision of the franchisor. For this reason, studying MUF as an explanatory variable of performance raises a potential problem of endogeneity and selection bias. Because the decision is not made randomly, the results can be biased and inconsistent. These problems regarding the impact of strategic decisions in terms of performance have previously been emphasized by Masten (1996), Hamilton and Nickerson (2003), Saussier and Yvrande-Billon (2004) and Chaudey and Fadairo (2010). We use the two-step Heckman method (Heckman, 1979) to handle this problem. It consists of first estimating a probit selection equation for the governance choice; here, the presence of MUF. This stage is used to calculate the non-selection hazard; that is, the inverse of Mills' ratio. In a second step, the regression equation for the performance includes the non-selection hazard as an additional parameter. The significance of the inverse of Mills' ratio highlights the presence of a selection bias.

We use the following probit model as the first step to estimate the probability that a network chooses MUF; that is, the self-selection decision. Consistent with the literature assessing why franchisors choose MUF versus SUF, the model is specified as follows:

$$
\begin{aligned}
\operatorname{Pr}\left(M_{i}=1\right)=\alpha_{0}+ & \alpha_{1} t_{i}+\alpha_{2} e_{i}+\alpha_{3} l_{i}+\alpha_{4} f r_{i}+\alpha_{5} s k_{i} \\
& +\alpha_{6} b_{i}+\alpha_{7} d_{i}+\alpha_{8} a_{i}+\alpha_{9}+s_{i}+\varepsilon_{i}
\end{aligned}
$$

where:

$i=$ franchisor

$M_{i}=$ dichotomous variable that takes the value 1 if there is at least one multi-unit

franchise in the network and 0 otherwise

$t_{i}=$ level of trust of the franchisor in the franchisee

$s k i=$ system know-how 
$e_{i}=$ environmental uncertainty

$S i=$ size of the franchised network

$f r i=$ behavioral uncertainty

$d_{i}=$ decision rights

$b_{i}=$ brand name value

$l i=$ advantages of franchising

$a_{i}=$ age

$\varepsilon i=$ error term

An endogenity problem may arise in this equation regarding the decision rights variable. Indeed, unobservable characteristics may simultaneously affect this variable and the outcome variable. There is no good instrument in the data for the decision rights variable ${ }^{3}$. For this reason, the instrumental variables method, or the test of exogeneity for a probit (tobit) model developed by Smith and Blundell (1986), cannot be performed.

To deal with this problem, the Heckman model is estimated once with the decision rights variable and once without this variable. As the estimation results are qualitatively similar, we conclude that the variable is not endogenous. The inverse of the Mills ratio $(\lambda)$, which captures the magnitude of the selection bias, is obtained from equation (1). In the second step of the Heckman method, that is, the equation for the performance $(P i)$, the parameter $\lambda$ is enclosed as an additional regressor. This second equation includes all the explanatory variables of the probit equation, less the variable advantages of franchising ${ }^{4}$.

\footnotetext{
${ }^{3}$ A good instrument satisfies two conditions: it has an explanatory power with respect to the suspected endogenous variable, and it does not influence directly the outcome variable.

${ }^{4}$ The Heckman method requires the inclusion in the first equation of at least one explanatory variable affecting the strategic choice (here MUF) but not directly the performance. In the estimations, the variable advantages of franchising (li) are used in this way.
} 


$$
\begin{aligned}
P_{i}=\lambda+ & \beta_{0}+\beta_{1} e_{i}+\beta_{2} t_{i}+\beta_{3} f r_{i}+\beta_{4} s k_{i} \\
& +\beta_{5} b_{i}+\beta_{6} d_{i}+\beta_{7} a_{i}+\beta_{8} s_{i}+\varepsilon_{i}
\end{aligned}
$$

If the inverse of the Mills ratio $(\lambda)$ is not significant, the self-selection decision variable, here MUF $(M i)$, can be introduced in the equation for the performance with no risk of selection bias. Regarding this last stage, that is, the OLS estimates for the network performance based on MUF, we control for heterocedasticity with the Breusch-Pagan test and for multicolinearity with the variance inflation factor (VIF). In addition, we control for the potential endogeneity. As good instrumental variables are not available due to the cross sectional and mainly qualitative data, we use a version of the Hausman specification test ${ }^{5}$. Finally, we check for the normality of the residues with the Skewness and Kurtosis tests.

4.1.2 Propensity score matching (PSM). As a complement to the Heckman method, PSM enables us to control whether the decision to use MUF provides the expected effects and whether these effects are attributable to the presence of this organizational form. In other words, PSM enables us to study what would have happened if the franchisor had not decided to use MUF. The method requires us to select a group of franchisors not using MUF (the control group) that are comparable to the group of franchisors using MUF (the treatment group). This selection is based on observable characteristics. The literature shows that PSM reduces the bias in the estimation of treatment effects when traditional regression methods are often unreliable because of the nonrandom assignment of individuals to the treatment and

\footnotetext{
${ }^{5}$ Using the reduced form $\left\{\begin{array}{l}Y_{1}=\alpha_{0}+\alpha_{1} X_{i}+v_{i} \\ Y_{2}=\pi_{0}+\pi_{1} X_{i}+w_{i}\end{array}\right.$ as an example, the procedure can be described as follows: first we get the residue $v i$ from the regression of $Y 1$ with the exogenous variables (in the reduced form), then we regress $Y 2$ as a function of $Y 1$ and $v i$. If the coefficient of $v i$ is significant, it is then not possible to reject the hypothesis of simultaneity.
} 
control groups. Thus, the estimation of the treatment effect can be biased by the existence of confounding factors. In this study, the confounding factors can be viewed as unobserved factors that may affect both the franchisor's performance and the franchisor's propensity to use MUF as a governance form (e.g., intrinsic managerial abilities and unobservable changes in the franchisor's operating environment). PSM corrects the estimations of the treatment effects by controlling for the existence of these confounding factors.

The method is based on the idea that the bias is reduced when there is a comparison of the outcomes using treated and control individuals (i.e., MUF and not MUF) who are as similar as possible. PSM was first introduced by Rosenbaum and Rubin (1983) on the propensity score in which the conditional probability of receiving treatment given $t r$, denoted $p(t r)$ as a matching measure. According to Cameron and Trivedi (2005), when the data justify the matching on tr, the matching based on the propensity score is also justified. The aim here is to estimate the average effect of the treatment group on the treated group $(\mathrm{Att})$.

$$
A t t \equiv E Y_{1 i}\left|D_{i}=1-E Y_{0 i}\right| D_{i}=1
$$

where, $\mathrm{Y}_{1 i}$ is the performance of the network $\mathrm{k}_{i}$ when the franchisor is using MUF and $\mathrm{Y}_{0 i}$ when it is otherwise and $\mathrm{D}=1 ; 0$ is the indicator of exposure to the treatment $(1=\mathrm{MUF}, 0$ did not use MUF). $E Y_{1 i} \mid D_{i}=1$ and $E Y_{0 i} \mid D_{i}=0$ are observable whereas $E Y_{0 i} \mid D_{i}=1$ and $E Y_{1 i} \mid D_{i}=0$ are not. They are called unobserved counterfactuals.

The following matching methods are relevant to estimate $\mathrm{Att}$ :

- Nearest neighbor: this method enables us the matching of each individual in the treatment group with the individual in the control group that has the closest propensity score. The problem could be that the distance between propensity scores can be very large. Following 
Cameron and Trivedi (2005, p. 899), a matching set can be defined as:

$$
A_{i}(p(t r))=p_{j}\left|\min _{j} \| p_{i}-p_{j}\right| \mid
$$

- Radius matching: unlike the previous method, it defines a neighborhood bounded by a radius that limits the differences that should be in the propensity scores for the matching.

- Kernet matching: the individuals in the treatment sample are compared to a the weighted average of the individuals in the control sample. The weights are inversely proportional to the distance between the propensity scores of the treatment and of the control group.

- Stratification matching: this method separates the propensity scores into categories (quartile). For each quartile, the method allows to match the treatment and the control individuals.

\subsection{Results}

4.2.1 Results from the Heckman method. The first set of estimates resulting from the Heckman method are presented in Table 2. These results highlight that the inverse of Mills' ratio $(\lambda)$ is not significant (model 2). In others words, there is no problem of selection bias. Therefore, we introduce the variable MUF (Mi) in the last stage of the estimations (model 3) as the core explanatory variable for the network performance, with the other independent variables (Age, Size, Franchisor's investment, Advertising rate) being used as control variables. We use the White's correction for the standard errors (Breusch-Pagan $\chi^{2}$ : 4.91, pvalue: 0.0268 ). In this equation (model 3) we do not find any severe multicolinearity (VIF: 1.12) or endogeneity problems.

Our estimations of model 3 show that the influence of MUF (Mi) on performance is significant and positive. In other words, this governance form impacts significantly and positively the network performance. 
For robustness checks, and because of the non-normality of the residues, highlighted by the Skewness and Kurtosis tests, we perfrom a Huber and Tukey biweights regression (model 4) and a quantile regression (model 5). These estimation methods address the problem of non-normality of the residues ${ }^{6}$. Our estimation results show that the significantly positive influence of MUF on the network performance is robust.

Table 2

Control for selection bias and first set of results

\begin{tabular}{|c|c|c|c|c|c|}
\hline & \multicolumn{2}{|c|}{ Heckman Method } & \multirow[t]{2}{*}{ OLS } & \multirow{2}{*}{$\begin{array}{c}\text { OLS } \\
\text { Huber and } \\
\text { Tukey }\end{array}$} & \multirow{2}{*}{$\begin{array}{l}\text { Quantile } \\
\text { regression }\end{array}$} \\
\hline & $\begin{array}{l}\text { First stage } \\
\text { (Probit) }\end{array}$ & $\begin{array}{c}\text { Second stage } \\
(\text { OLS })\end{array}$ & & & \\
\hline & $\operatorname{Mi}(1)$ & $P i(2)$ & $P i(3)$ & $P i(4)$ & $P i(5)$ \\
\hline $\begin{array}{l}\text { Environmental } \\
\text { uncertainty }\end{array}$ & $\begin{array}{c}-0.0942^{* * *} \\
(0.0346)\end{array}$ & $\begin{array}{l}-0.720^{* *} \\
(0.293)\end{array}$ & & & \\
\hline $\begin{array}{l}\text { Decision } \\
\text { rights }\end{array}$ & $\begin{array}{c}-0.0131 \\
(0.00830)\end{array}$ & $\begin{array}{l}0.147^{* *} \\
(0.0621)\end{array}$ & & & \\
\hline $\begin{array}{l}\text { System } \\
\text { know-how }\end{array}$ & $\begin{array}{c}0.0215 \\
(0.0127)\end{array}$ & $\begin{array}{l}0.297^{* * *} \\
(0.0781)\end{array}$ & & & \\
\hline Brand name & $\begin{array}{c}0.027 \\
(0.0265)\end{array}$ & $\begin{array}{c}0.528^{* * *} \\
(0.182)\end{array}$ & & & \\
\hline $\begin{array}{l}\text { Behavioral } \\
\text { uncertainty }\end{array}$ & $\begin{array}{c}0.0542 \\
(0.0445)\end{array}$ & $\begin{array}{c}0.128 \\
(0.268)\end{array}$ & & & \\
\hline Trust & $\begin{array}{l}-0.0134 \\
(0.0311)\end{array}$ & $\begin{array}{l}0.0465 \\
(0.175)\end{array}$ & & & \\
\hline $\begin{array}{l}\text { Network } \\
\text { age }\end{array}$ & $\begin{array}{c}0.018 \\
(0.0158)\end{array}$ & $\begin{array}{c}0.024 \\
(0.117)\end{array}$ & $\begin{array}{c}0.073 \\
(0.0712)\end{array}$ & $\begin{array}{c}0.04609 \\
(0.0689)\end{array}$ & $\begin{array}{c}0.1277 \\
(0.12708)\end{array}$ \\
\hline Size & $\begin{array}{c}0.00377^{* * *} \\
(0.00123)\end{array}$ & $\begin{array}{c}0.00368 \\
(0.00325)\end{array}$ & $\begin{array}{l}0.000499 \\
(0.00121)\end{array}$ & $\begin{array}{c}0.00059 \\
(0.00194)\end{array}$ & $\begin{array}{c}-0.001 \\
(0.0035)\end{array}$ \\
\hline $\begin{array}{l}\text { MUF } \\
\text { (dummy) }\end{array}$ & & & $\begin{array}{l}2.814^{* *} \\
(1.191)\end{array}$ & $\begin{array}{l}2.185 * * \\
(1.085)\end{array}$ & $\begin{array}{l}3.713 * \\
(2.000)\end{array}$ \\
\hline
\end{tabular}

\footnotetext{
${ }^{6}$ The first method reduces the influence of outliers in the estimation. It consists of applying a regression in which weights based on absolute residuals are obtained. A new regression is then performed using these weights (Hamilton, 1991). Quantile regression (Koenker and Bassett, 1978) minimizes the sum of the absolute deviations from the median $(\theta=0.5)$. This method is robust to non-normal errors and outliers.
} 


\begin{tabular}{|c|c|c|c|c|c|}
\hline $\begin{array}{l}\text { Franchisor's } \\
\text { investment }\end{array}$ & & & $\begin{array}{l}0.358^{* *} \\
(0.168)\end{array}$ & $\begin{array}{c}0,01548 \\
(0.1302)\end{array}$ & $\begin{array}{c}0,3843 \\
(0.24019)\end{array}$ \\
\hline $\begin{array}{l}\text { Advertising } \\
\text { rate }\end{array}$ & & & $\begin{array}{c}0,0448 \\
(0.0625)\end{array}$ & $\begin{array}{c}0,0771 \\
(0.1400)\end{array}$ & $\begin{array}{c}-0,0995 \\
(0.2582)\end{array}$ \\
\hline $\begin{array}{l}\text { Franchise } \\
\text { advantage }\end{array}$ & $\begin{array}{c}0,0181 \\
(0.0202)\end{array}$ & & & & \\
\hline Constant & $\begin{array}{c}-0,38 \\
(0.844)\end{array}$ & $\begin{array}{c}6,704 \\
(5.880)\end{array}$ & $\begin{array}{c}28.09^{* * *} \\
(2.297)\end{array}$ & $\begin{array}{c}31,239 \\
(1.9532)\end{array}$ & $\begin{array}{l}31.517 * * * \\
(3.6023)\end{array}$ \\
\hline $\begin{array}{l}\text { Inverse of } \\
\text { Mills ratio } \\
\text { Lambda }(\lambda)\end{array}$ & & $\begin{array}{c}6,472 \\
(4.623)\end{array}$ & & & \\
\hline$N$ & 166 & 166 & 166 & 166 & 166 \\
\hline pseudo $R^{2}, R^{2}$ & & & 0,0905 & & 0415 \\
\hline$\chi^{2}, F$ & & $38.11^{* * *}$ & $4.53^{* * *}$ & $1.72^{* *}$ & \\
\hline
\end{tabular}

Note: Significant $*$ at the $10 \%$ level, $* *$ at the $5 \%$ level, ***at the $1 \%$ level.

Standard errors are in brackets.

4.2.2 Results from PSM. To carry out the estimation of $p(t r)$, we study the role played by several franchisor's characteristics on the probability of introducing MUF as the governance structure. The treated networks are those using MUF as the governance form, whereas the controls are the networks that do not use MUF at all. That is why we perform a probit regression with the dummy variable MUF as the dependent variable.

As independent variables, we use the same independent variables as in the Heckman specification. These independent variables define characteristics of the franchisors using MUF. The estimation results of PSM are the same as the probit estimations (1) in Table 2. The balancing property condition is satisfied after the partition of the sample into six homogeneous blocks, according to their estimated propensity score value. Table 3 reports the results of Att, which were calculated by using the following matching methods: nearest neighbor, radius, kernet and stratification. As highlighted by Table 3, the PSM results confirm the Heckman results, providing evidence that franchising networks using MUF have higher performance than the networks that do not use it as a governance form. 
This key result calls for us to go further, and to take into account the percentage of MUF in the franchised network instead of the dummy variable $(M i)$, as well as the different contexts distinguished by the testable predictions (Hypotheses 1-6). Regarding this last point, a nonparametric analysis is required and a reasoning in three dimensions to study the influence of MUF (1), on the network performance (2), in a specific context (3): business-format, level of behavioral uncertainty, decentralization level of decision rights, level of trust in the franchise relationship, level of environmental uncertainty. We deal with these issues in the following section.

\section{Table 3}

Results of PSM estimations

\begin{tabular}{lccl}
\cline { 2 - 4 } & Treated & Control & ATT \\
\hline $\begin{array}{l}\text { Nearest neighbor } \\
\text { matching }\end{array}$ & 106 & 35 & $\begin{array}{l}3.675^{* * *} \\
(1.231)\end{array}$ \\
Radius matching & 106 & 56 & $\begin{array}{l}3.122^{* * *} \\
(0.428)\end{array}$ \\
Kernet matching & 106 & 56 & $\begin{array}{l}3.065^{* * *} \\
(1.917)\end{array}$ \\
Stratification matching & 105 & 57 & $\begin{array}{l}3.148^{* * *} \\
(1.176)\end{array}$ \\
\hline $\begin{array}{l}\text { Note: Significant *at the } 10 \% \text { level, } \\
\text { Standard errors are in brackets. }\end{array}$ & & &
\end{tabular}

\section{Impact of Multi-unit franchising on the network performance}

\subsection{Estimations}

5.1.1Methodology. The additive regression analysis enables a reasoning in three dimensions, as required by the hypotheses. In addition, it is a nonparametric method, which overcomes the problem of non-normality affecting the data. The nonparametric regression analysis is designed to avoid any specific assumption about the residues, which allows a better 
distribution of the parameters. In other words, this method relaxes the assumption of linearity. The only restriction imposed is that the function $g($.$) is smooth. For this reason, such type of$ methods are also called smoothing methods.

Among the nonparametric methods, additive regression specifies the mean of the response variable as the sum of the smooth functions of the regressors. When the response variable does not follow a normal distribution, the method can be generalized, as proposed by Hastie and Tibshirani (1986). The generalized additive model is a generalized linear model, which implies a sum of smooth functions of covariates ${ }^{7}$.

Our model can be written as follows:

$$
P_{i}=g_{1}\left(e_{i}\right)+g_{2}\left(t_{i}\right)+g_{3}\left(f r_{i}\right)+g_{4}\left(s k_{i}\right)+g_{5}\left(b_{i}\right)+g_{6}\left(d_{i}\right)+\varepsilon_{i}
$$

The simple regression smoother is used to fit the partial regression function $g_{\mathrm{j}}($.$) .$

5.1.2 Results. Table 4 presents the estimation results of six additive models (8-13) regarding the influence of MUF expressed as a percentage, on the performance, taking into account six contextual variables: brand name value, system know-how, level of behavioral uncertainty, delegation level of decision rights, level of trust in the franchise relationship, and level of environmental uncertainty. In addition, for robustness checks, we report the estimation results of a Huber and Tukey regression (model 6) and of a quantile regression (model 7), including all the explanatory variables ${ }^{8}$. The good global significance of these

\footnotetext{
7 For more detailed information, see Wood (2006).

${ }^{8}$ OLS estimates with all the explanatory variables do not present any problem of endogeneity, heterogeneity, or multicolinearity (Breusch-Pagan $\chi^{2}$ : 0.44, pvalue: 0.5048; VIF: 1.20). However, as in the preceding case of model (3), the normality tests (Skewness and Kurtosis) highlight the non-normality of the residues $\left(\chi^{2}: 14.36\right.$, pvalue: 0.0008 ). For this reason, this estimation method is not appropriate here.
} 
models is highlighted by $\mathrm{R}^{2}$ (additive models) and Pseudo $\mathrm{R}^{2}$ (quantile regression), which are quite high for cross-sectional data (between $21.58 \%$ and $37 \%$ ), and by the $\chi^{2}$ test (Huber and Tukey regression).

Furthermore, regarding the additive models, we perform an analysis of deviance by means of $\chi^{2}$ tests for linearity that compares each additive model with its linear version. Such tests for linearity show that, in all the cases, the difference is highly statistically significant, which means that the additive nonparametric regressions provide a more accurate estimate of the relationship between the performance and the independent variables. Complementary results are provided by additive models including interactive terms; that is, for each model, the interaction of MUF (expressed as a percentage) with a contextual variable (models 14-19, Table 5). Here again, the high level of the $\mathrm{R}^{2}$ (between $28.6 \%$ and $39.5 \%$ ) underlines the good global significance of the estimations.

The results are robust and clearly emphasize the significant positive impact of MUF on the network performance. The two models including all the study variables (models 6 and 7) highlight the relevance of the theoretical framework. Indeed, except for trust, and behavioral uncertainty in model (7), all of the explanatory variables exert a significant influence on the MUF network performance. The signs of the impact on performance are coherent, and indicate a negative impact of environmental uncertainty, a positive impact of the delegation of decision rights, a positive impact of the system know-how, and a positive impact of the brand name. These results are confirmed by additive nonparametric regressions (8) to (13), except for the variable environmental uncertainty. In the additive models, trust and behavioral uncertainty have a significant effect.

The estimations are completed with models enclosing interactive terms. As suggested by the hypotheses, the interaction of MUF with the contextual variables derived from the analytical framework has a significant effect on the network performance in all of the cases. 
Estimates based on the tensor product method are presented in Table 5 (models 14 to 19). For robustness checks, we perform, additional estimations using a variant of the tensor product method in Table 6. Here again, the impact of the interactive terms on the performance is highly significant.

Parametric methods estimate the slope of linear relationships between independent and dependent variables, this slope is supposed to be the same whatever the level of the independent variable. Nonparametric estimations provide more complex information. Thus, regarding the additive nonparametric estimations (models 8 to 13), Table 4 reports four pieces of information for each independent variable (e.g., the MUF\% in model 8). First, the smoothing term of the partial-regression function (e.g., 7.289). Second, the result of the Fisher's test regarding this smoothing term, which indicates whether the effect of the independent variable on the performance is significant (e.g., 4.711***). Third, the type of relationship between the independent variable and the performance, that is, decreasing (DR) or increasing (IR). Finally, the point (i.e., the level of the independent variable) from which the influence does not significantly differ from zero; for example, IR: 0.25 regarding MUF in model (8).

As MUF is expressed as a percentage, this specific result means that the higher the percentage of MUF in the network, the higher the performance (IR), as long as the percentage of MUF in the network is below 25\%. Similar thresholds are highlighted by the other estimation results: $20.5 \%$ in model (9), $55 \%$ in model (11), $8.9 \%$ in model (12), $66.7 \%$ in model $(13)^{9}$. This is a key result of the nonparametric estimations, suggesting that MUF improves the network performance, but only up to a certain threshold. In others words, some mix between MUF and SUF is required, with the mix level depending on the context: delegation level of decision rights (model 9), brand name value (model 11), level of trust

\footnotetext{
9 The effect of MUF in model (10) is not significant, as highlighted by the Fisher's test.
} 
(model 12), and behavioral uncertainty (model 13). The point from which the effect of the explanatory variable is null is derived from the graphs regarding the partial-regression functions (see Figure 2). The points in each graph of Figure 2 are partial residuals for the corresponding predictor, removing the effect of the other predictor. Graphical analysis is continued and developed hereafter with the three-dimensional perspective plots.

\subsection{Graphical analysis}

The fitted surfaces for the additive nonparametric regressions are presented in Figure 3. Perspective plots are predictions of the nonparametric models based on the data. Each graph represents the impact of MUF (\%), in addition with a contextual variable, on the network performance. In accordance with the research model, six contextual variables are successively taken into account: brand name (a), behavioral uncertainty (b), environmental uncertainty (c), system know-how (d), trust (e), decision rights (f). As previously mentioned, nonparametric regression analysis relaxes the assumption of linearity, substituting the much weaker assumption of a smooth population regression function. Although the gain is a more accurate estimate of the regression function, relaxing the assumption of linearity has a cost in the difficulty of understanding the results. A considerable advantage of the additive regression model is that it reduces to a series of two-dimensional partial-regression problems, which facilitates the interpretation. Thus, for each three-dimensional perspective plot of the fitted additive regression surface relating the performance to MUF and to a contextual variable, the slices of the surface in the direction of MUF (i.e., holding the contextual variable constant at various values) are all parallel. Similarly, the slices in the direction of the contextual variable (holding MUF constant) are parallel, which allows for interpretation. All of the perspective plots highlight a relationship for both MUF and each contextual variable with performance. This result provides important support to the analytical framework. In addition, this relationship is not linear, because each perspective plot consists of a set of curves versus lines. 
Table 4

Estimation results

\begin{tabular}{|c|c|c|c|c|c|c|c|c|}
\hline & \multirow{2}{*}{$\begin{array}{c}\text { OLS } \\
\text { Huber and Tukey } \\
\mathrm{P}_{i}(6)\end{array}$} & \multirow{2}{*}{$\begin{array}{l}\text { Quantile } \\
\text { regression } \\
\mathrm{P}_{i} \quad \text { (7) }\end{array}$} & \multicolumn{6}{|c|}{ Additive models $^{\dagger}$} \\
\hline & & & $\mathrm{P}_{i}$ & $\mathrm{P}_{i} \quad(9)$ & $\mathrm{P}_{i} \quad(10)$ & $\mathrm{P}_{i}$ & $\mathrm{P}_{i} \quad(12)$ & $\mathrm{P}_{i} \quad(13)$ \\
\hline MUF(\%) & $\begin{array}{l}0.944^{*} \\
(0.511)\end{array}$ & $\begin{array}{l}1.384^{* *} \\
(0.667)\end{array}$ & $\begin{array}{c}7.289 \\
4.711^{* * *} \\
\text { IR: } 0.25\end{array}$ & $\begin{array}{c}7.218 \\
5.775^{* *} \\
\text { IR:0.205 }\end{array}$ & $\begin{array}{c}1.254 \\
1.459 \\
\text { IR: } 0.833\end{array}$ & $\begin{array}{c}7.278 \\
5.024 * * * \\
\text { IR: } 0.55\end{array}$ & $\begin{array}{c}2.288 \\
9.228 * * * \\
\text { IR: } 0.089\end{array}$ & $\begin{array}{c}6.743 \\
3.502 * * * \\
\text { IR:0.667 }\end{array}$ \\
\hline $\begin{array}{l}\text { Environmental } \\
\text { uncertainty }\end{array}$ & $\begin{array}{c}-0.375 * * * \\
(0.135)\end{array}$ & $\begin{array}{c}-0.475 * * * \\
(0.176)\end{array}$ & $\begin{array}{l}3.005 \\
1.973 \\
\text { DR: } 6\end{array}$ & & & & & \\
\hline $\begin{array}{l}\text { Decision } \\
\text { rights }\end{array}$ & $\begin{array}{r}0.160^{* * * *} \\
(0.0318)\end{array}$ & $\begin{array}{l}0.128 * * \\
(0.0415)\end{array}$ & & $\begin{array}{c}1 \\
4.285^{* *} \\
\text { DR: } 50\end{array}$ & & & & \\
\hline $\begin{array}{l}\text { System } \\
\text { knowhow }\end{array}$ & $\begin{array}{l}0.157 * * * \\
(0.0461)\end{array}$ & $\begin{array}{l}0.138 * * \\
(0.0601)\end{array}$ & & & $\begin{array}{l}4.331 \\
13.05^{* * *} \\
\text { IR: } 38\end{array}$ & & & \\
\hline Brand name & $\begin{array}{c}0.463 * * * \\
(0.100)\end{array}$ & $\begin{array}{c}0.503 * * * \\
(0.131)\end{array}$ & & & & $\begin{array}{l}6.445 \\
4.532 * * * \\
\text { IR: } 20\end{array}$ & & \\
\hline Trust & $\begin{array}{l}0.0986 \\
(0.114)\end{array}$ & $\begin{array}{l}0.0977 \\
(0.150)\end{array}$ & & & & & $\begin{array}{l}7.695 \\
3.450^{* * *} \\
\text { IR: } 9\end{array}$ & \\
\hline $\begin{array}{l}\text { Behavioral } \\
\text { uncertainty }\end{array}$ & $\begin{array}{l}0.291 * \\
(0.166)\end{array}$ & $\begin{array}{c}0.329 \\
(0.217)\end{array}$ & & & & & & $\begin{array}{l}1.861 \\
2.296^{* *} \\
\text { IR: } 8.23\end{array}$ \\
\hline \multicolumn{9}{|l|}{ Constant } \\
\hline & $\begin{array}{c}10.36 * * * \\
(3.235)\end{array}$ & $\begin{array}{c}11.67 * * * \\
(4.224)\end{array}$ & $\begin{array}{r}0.0283068^{* * *} \\
(0.0004603)\end{array}$ & $\begin{array}{l}35.5177 * * * \\
(0.546)\end{array}$ & $\begin{array}{c}35.5177 * * * \\
(0.4536)\end{array}$ & $\begin{array}{c}35.5177^{* * *} \\
(0.4661)\end{array}$ & $\begin{array}{c}35.5177 * * * \\
(0.4974)\end{array}$ & $\begin{array}{c}35.5177 * * * \\
(0.5046)\end{array}$ \\
\hline
\end{tabular}




\begin{tabular}{|c|c|c|c|c|c|c|c|c|}
\hline $\mathrm{N}$ & 166 & 166 & 166 & 166 & 166 & 166 & & \\
\hline $\mathrm{R}^{2}$, Pseudo $\mathrm{R}^{2}$ & & 21.58 & 23.6 & 22 & 37 & 33.5 & 24.2 & 22 \\
\hline$x^{2}$ & $19.82 * * *$ & & & & & & & \\
\hline AIC & & & 1135.809 & 1103.513 & 1065.686 & 1082.259 & 1100.458 & 1103.931 \\
\hline Freedom & & & 11.29 & 9.22 & 6.58 & 14.72 & 10.98 & 9.6 \\
\hline$\chi^{2}$ test for linearity & & & $7870.424 * * *$ & $1260.819 * * *$ & $1645.709^{* * *}$ & $1689.136^{* * *}$ & $1709.702 * * *$ & $1083.395^{* * *}$ \\
\hline
\end{tabular}

Note: * Signifiant at the $10 \%$ level, $* *$ at the $5 \%$ level, $* * *$ at the $1 \%$ level. $\uparrow$ Smoothes terms. DR: Decreasing effect. IR: Increasing effect.
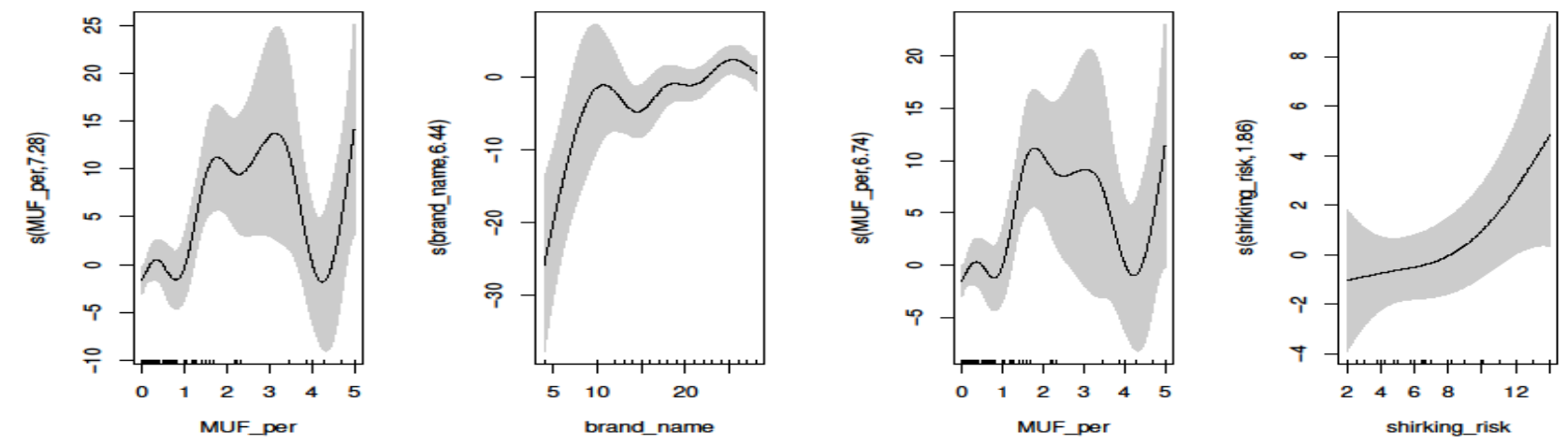

(a)

(b)

FIGURE 2. PARTIAL-REGRESSION FUNCTIONS FOR ADDITIVE NONPARAMETRIC MODELS (estimations 8 to 13).

Gray area gives point-wise $95 \%$ confidence envelopes around the fit. 


\section{Table 5}

\section{Interactive structure}

\begin{tabular}{|c|c|c|c|c|c|c|}
\hline & \multicolumn{6}{|c|}{ Additive models with interactive terms \pm 1} \\
\hline & $\mathrm{Pi}(14)$ & $\operatorname{Pi}(15)$ & $\operatorname{Pi}(16)$ & $\operatorname{Pi}(17)$ & $P i(18)$ & $\operatorname{Pi}(19)$ \\
\hline $\operatorname{MUF}(\%)$ & $\begin{array}{c}7,949 \\
3.473 * * *\end{array}$ & $\begin{array}{c}7,735 \\
5.621 * * *\end{array}$ & $\begin{array}{c}5,56 \\
1,254\end{array}$ & $\begin{array}{c}7,64 \\
2.467 * *\end{array}$ & $\begin{array}{c}2,21 \\
6.809^{* * *}\end{array}$ & $\begin{array}{c}5,397 \\
2.375 * *\end{array}$ \\
\hline $\begin{array}{l}\text { Environmental } \\
\text { uncertainty }\end{array}$ & $\begin{array}{c}6,946 \\
3.005^{* * *}\end{array}$ & & & & & \\
\hline Decision rights & & $\begin{array}{c}1 \\
3.495^{*}\end{array}$ & & & & \\
\hline $\begin{array}{l}\text { System } \\
\text { know-how }\end{array}$ & & & $\begin{array}{c}5,328 \\
4.617 * * *\end{array}$ & & & \\
\hline Brand name & & & & $\begin{array}{c}5,827 \\
3.832 * * *\end{array}$ & & \\
\hline Trust & & & & & $\begin{array}{l}7,737 \\
3.23 * *\end{array}$ & \\
\hline $\begin{array}{l}\text { Behavioral } \\
\text { uncertainty }\end{array}$ & & & & & & $\begin{array}{l}1,609 \\
0,716\end{array}$ \\
\hline $\begin{array}{l}\text { Interaction MUF } \times \\
\text { contextual variable }\end{array}$ & $\begin{array}{c}9,8 \\
4.843^{* * *}\end{array}$ & $\begin{array}{c}2,469 \\
3.524 * *\end{array}$ & $\begin{array}{c}8,601 \\
2.626^{* * *}\end{array}$ & $\begin{array}{c}4 \\
2.259 *\end{array}$ & $\begin{array}{c}5,114 \\
5.204 * * *\end{array}$ & $\begin{array}{c}7,782 \\
2.499 * * *\end{array}$ \\
\hline Constant & $\begin{array}{c}34.7724^{* * *} \\
(0.5081)\end{array}$ & $\begin{array}{l}35.5266^{* * * *} \\
(0.4949)\end{array}$ & $\begin{array}{c}34.7161^{* * *} \\
(0.5022)\end{array}$ & $\begin{array}{c}35.0694 * * * \\
(0.6147)\end{array}$ & $\begin{array}{c}35.2360 * * * \\
(0.4736)\end{array}$ & $\begin{array}{l}34.9335 * * * \\
(0.5188)\end{array}$ \\
\hline$N$ & 166 & 166 & 166 & 166 & 166 & 166 \\
\hline$R^{2}$ & 44,5 & 26 & 47 & 36,5 & 36,9 & 30,1 \\
\hline$A I C$ & 1061,467 & 1097,546 & 1049,615 & 1077,818 & 1074,612 & 1091,41 \\
\hline Freedom & 25,69 & 12,2 & 20,49 & 18,47 & 16,06 & 15,79 \\
\hline
\end{tabular}

Note: * Signifiant at the $10 \%$ level, ** at the $5 \%$ level, *** at the $1 \%$ level.

Standard errors are in brackets.

\pm The smooth term that produces a full tensor product smooth is presented here, which is more appropriate when the main effects are not present and the variables are not in the same measure unit. 
$¥$ These smooth terms cannot be directly interpreted.

The study of each perspective plot separately enables us to confront more precisely the hypotheses with the data. As we are dealing with non-linear relationships, the comments on the hypotheses cannot be summed up as "validated" or "non-validated" as they could be with parametric estimations. The relations between the variables are more complex in this case, as, for example, each hypothesis can be validated on a specific interval of the explanatory variable, but not on the other one.

Regarding H1, the graphs (a) and (a') highlight that MUF increases performance between 0 and $30 \%$ in the context of a strong brand name. This result suggests that in a context of a high-value brand name, the highest performance is reached with a $30 \%$ level of MUF. Hypothesis $\mathrm{H} 2$ finds empirical support, with the estimation results plotted in graphs (b), (b'). In a context of shirking, the higher the percentage of MUF in the network, the higher the performance. Broadly speaking, the interaction of behavioral uncertainty with MUF has a positive effect on the network performance. The estimations regarding $\mathrm{H} 3$ are plotted in graphs (c) and (c'). The key evidence from these three dimensional perspective plots is the existence of cycles in the impact of MUF on the performance, depending on environmental uncertainty. Thus, a first threshold of $8 \%$ can be distinguished, suggesting that, in a context of environmental uncertainty, an increase in MUF improves the performance, to the threshold of $8 \%$ of MUF in the network. Relating to H4, the surfaces (d) and (d') address the system know-how context. The graphs are consistent with the estimation results presented in Table 4 model (10). In this context, the level of MUF has no significant effect on the performance, whereas the level of system know-how does impact the performance. In fact, in all the models including the system know-how variable, the impact of the level of MUF is not significant. The graphs (e) and (e') relate to H5 and reveal that an increase of MUF improves the 
performance in the network, regardless of the level of trust. Thresholds between the level of MUF and trust are highlighted, depending on the level of trust. Finally, graphs (f) and (f') regard hypothesis 6 and show that, in a context of delegation of decision rights, MUF increases the performance until $30 \%$. The plots also reveal that a high level of decision rights increases the performance.
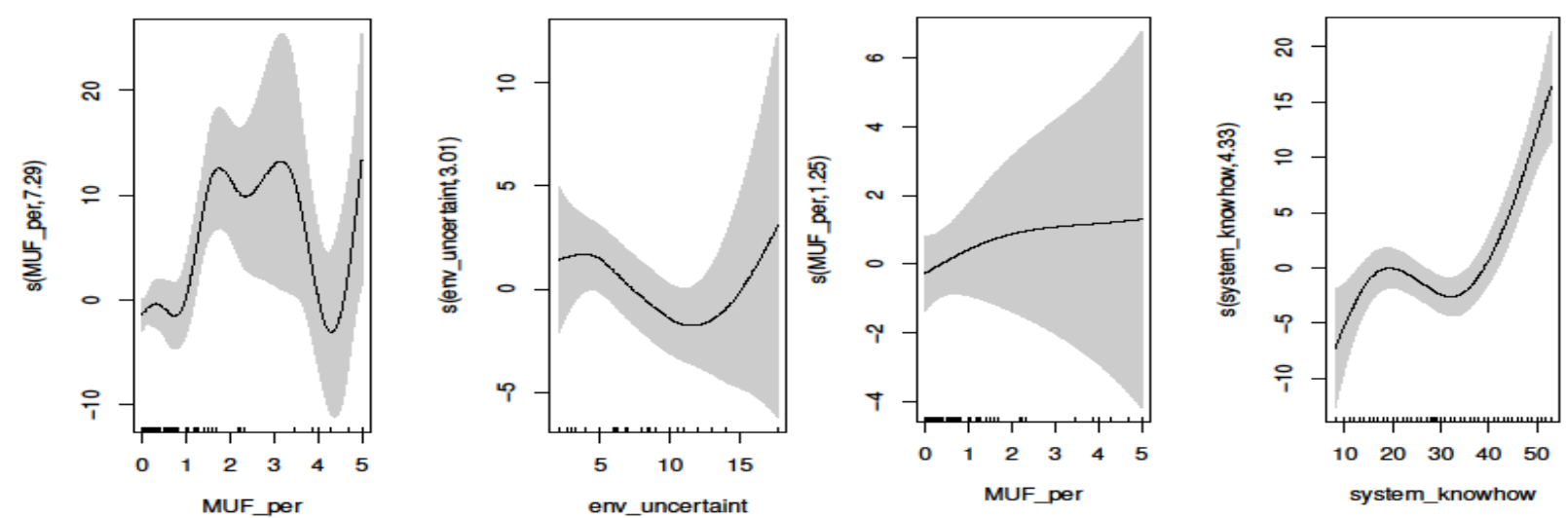

(c)

(d)
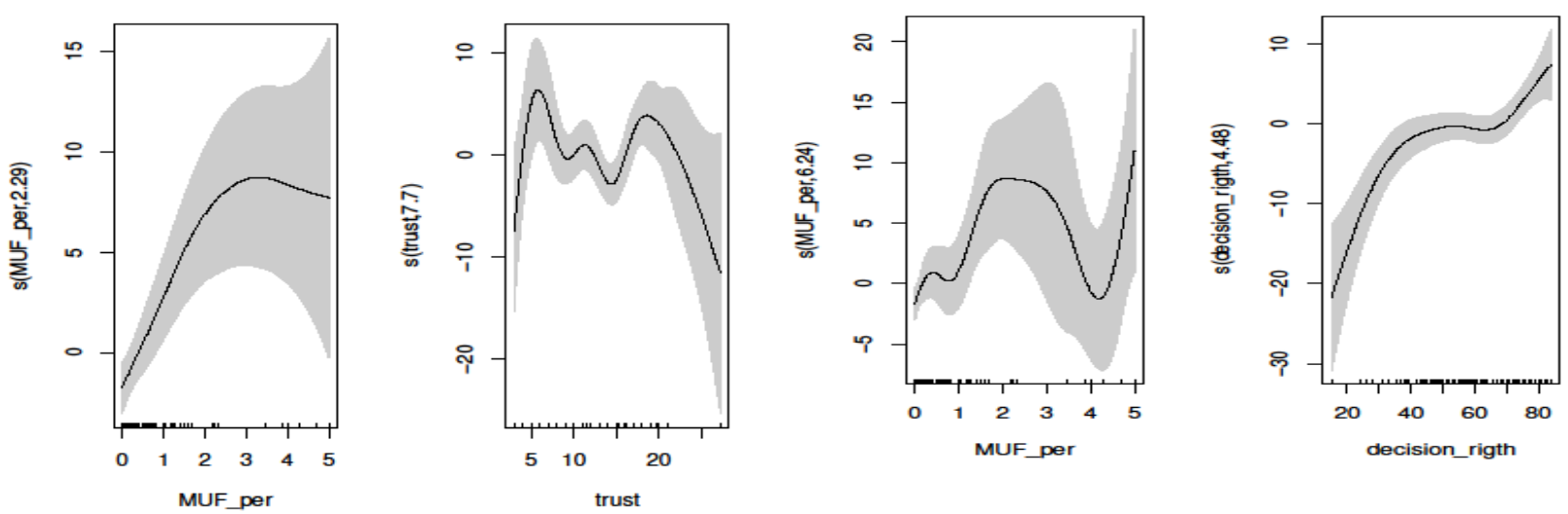

(e)

(f)

FIGURE 2. PARTIAL-REGRESSION FUNCTIONS FOR ADDITIVE NONPARAMETRIC MODELS (estimations 8 to 13). Gray area gives point-wise $95 \%$ confidence envelopes around the fit. 


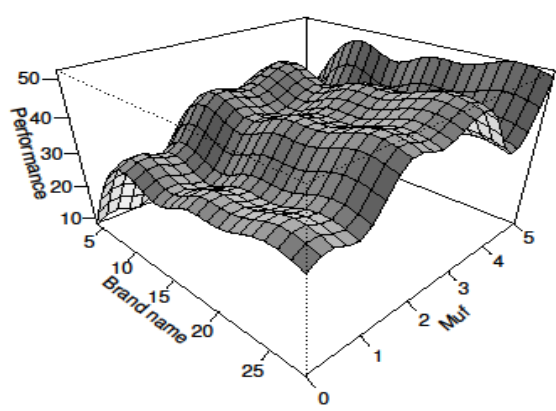

(a) Perspective plots related to $\mathrm{H} 1$

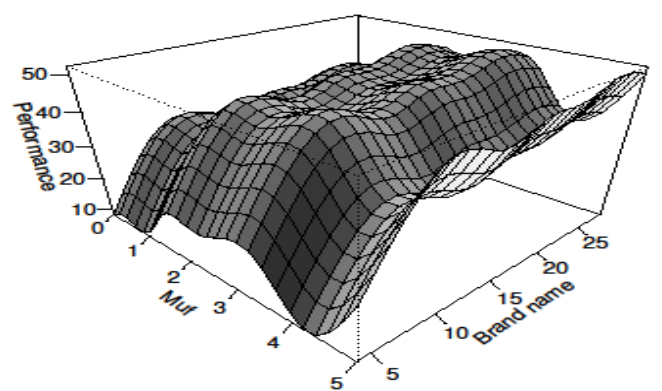

(a’)

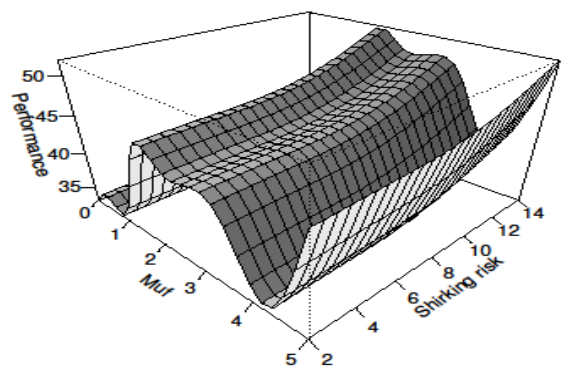

(b) Perspective plots related to H2

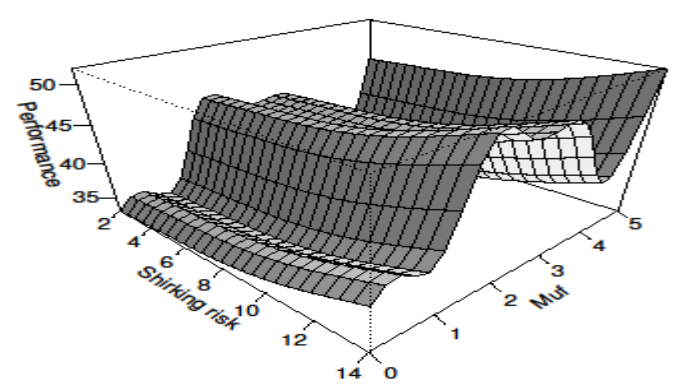

(b')

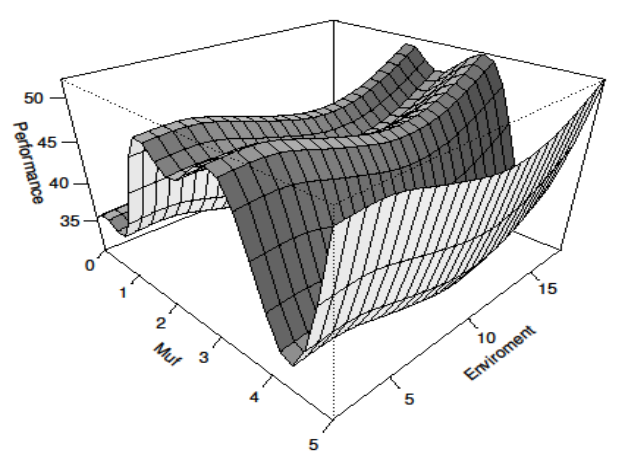

(c)
Perspective plots related to $\mathrm{H} 3$

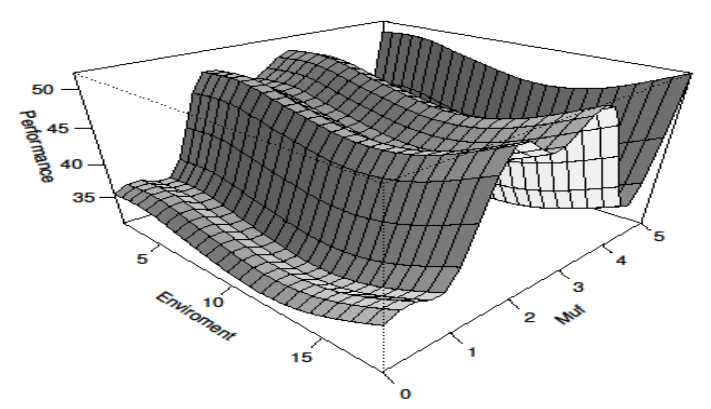

(c')

FIGURE 3: PERSPECTIVE PLOTS OF THE FITTED ADDITIVE REGRESSION SURFACES 


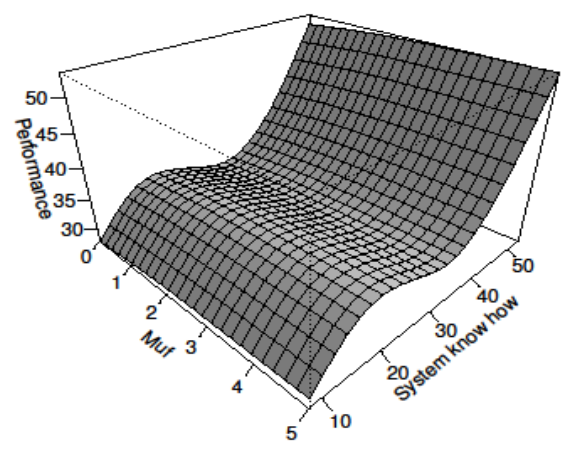

(d) Perspective plots related to H4

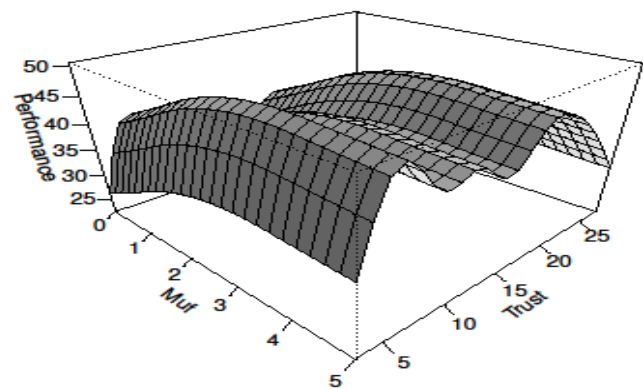

(e)

Perspective plots related to $\mathrm{H} 5$

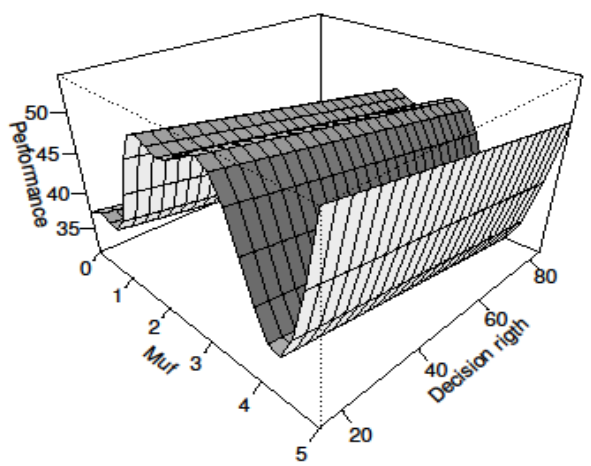

(f)

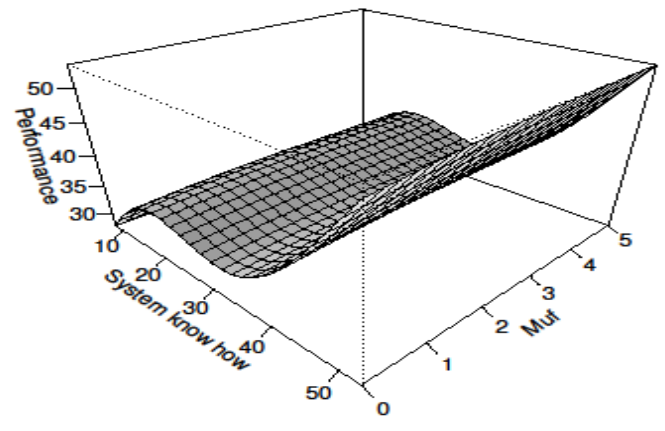

(d')

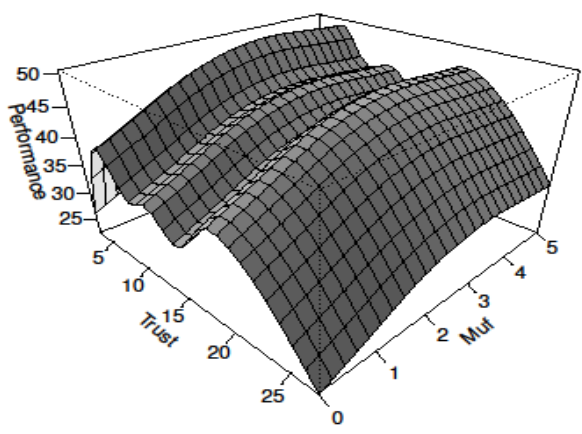

(e’)

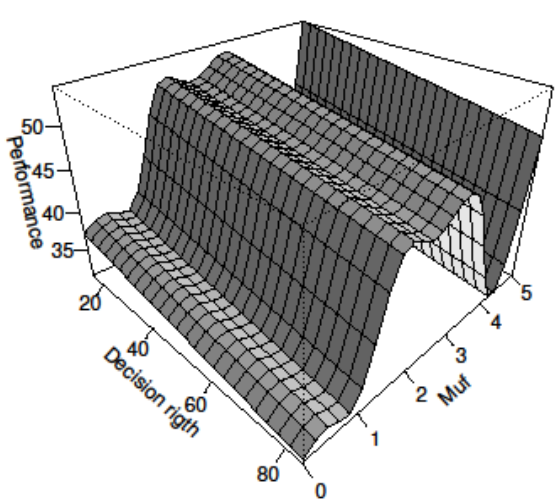

$\left(f^{\prime}\right)$ 


\section{Conclusion}

This paper deals with the impact of MUF on the network performance while controlling for selection and endogeneity bias related to the choice of an organizational form as explanatory variable. The key results can be summarized as follows: the use of MUF in the network significantly and positively impacts the performance. However, the results based on nonparametric models highlight thresholds from which the performance effect stabilizes (e.g., in the case of brand name and system knowhow as contextual variables, where the threshold is about $30 \%$ of MUF) and even cycles (taking into account the levels of trust, behavioral uncertainty, and delegation of decision rights). In addition, consistent with the hypotheses derived from the theoretical framework, we find evidence of interaction effects between MUF and each contextual variable, except for the variable system know-how.

This study has important implications for both researchers and franchising practitioners. To the best of our knowledge, this is the first study that offers an empirical test of the major determinants of MUF network performance by applying organizational economics theories (agency theory, transaction cost theory and property rights theory) and the relational governance view. Overall, the data provide support of our research model. Furthermore, the results of the study enable to develop new perspectives for future research. Specifically, the mix between multi-unit franchisees and single-unit franchisees in the network opens up new directions for future research. Both theoretical and additional empirical evidence would be required to explain the relationship between SUF and MUF within a franchising network. In addition, this study highlights the existence of cycles regarding the effect of an organizational form on performance. Further research is required to understand the turning points. Moreover, in addition to the mix between MUF and SUF in the network, the relationship between multi-unit franchising and proportion of company-owned outlets may 
also influence franchise system performance. For instance, the franchisor's decision rights are more diluted under MUF than under SUF because the franchisor transfers more decision management rights to the multi-unit franchisees. Under MUF, the franchisees have more decision making power regarding monitoring of local outlets, local human resource management and knowledge transfer between headquarters and local outlets. In this case, the franchisor may compensate the dilution of decision rights under MUF by an increase of control through more company-owned outlets. As a result, future research has to investigate the relationship between MUF and the proportion of company-owned outlets and its impact on performance.

In terms of managerial implications, the results show that the performance of franchise networks depends on the mix between MUF and SUF that is influenced by different contingency factors, such as uncertainty, brand name, trust, network age, size, and sector, or a combination of such variables.

Finally, two major limitations of the study have to be acknowledged. First, the data do not allow to differentiate between area development versus sequential MUF. Hence we could not examine the performance differences between both forms. Second, in this study, the performance measurement is based on subjective indicators. While objective measures have greater validity, most of the franchise systems in this survey do not disclose financial data. Although the literature has demonstrated that there is a strong positive correlation between objective and subjective performance indicators, future studies should test the model by using both subjective and objective performance indicators (Crook et al., 2008). 


\section{References}

Anderson, E., 1985, The salesperson as outside agent or employee: a transaction cost analysis, Marketing Science, 4, 234-254.

Anderson, J. C., and S. A. Narus, 1990, A model of distributor firm and manufacturer firm working partnerships, Journal of Marketing, 54, 42-58.

Armstrong J.S., T.S. Overton, 1977, Estimating nonresponse bias in mail surveys, Journal of Marketing Research, 16, 396-402.

Barthélemy, J., 2008, Opportunism, knowledge, and the performance of franchise chains, Strategic Management Journal, 29, 1451-1463.

Barthélemy, J., 2011, Agency and institutional influences on franchising, Journal of Business Venturing, 26, 93-103.

Bates T., 1998, Survival Patterns Among Newcomers to Franchising, Journal of Business Venturing, 13, 113-130.

Brickley J.A, 1999, Incentive Conflicts and Contracting: Evidence from Franchising, Journal of Law and Economics, 42: 645-774.

A. Cameron and P. Trivedi, 2005, Microeconomics: Methods and Applications, Cambridge University Press, New-York.

Caves R.E., W.F. Murphy, 1976, Franchising: firms, markets and intangible assets, Southern Economic Journal, 42, 572-86.

Celly K.S. and G.L. Frazier, 1996, Outcome-based and behavior-based coordination efforts in channel relationships, Journal of Marketing Research 33, 2, 200-210.

Chaudey M. and M. Fadairo, 2010, Contractual design and networks performance: empirical evidence from franchising, Applied Economics, 42, 529-533.

Cochet O, J. Dormann and T. Ehrmann, 2008, Capitalizing on franchisee autonomy: Relational forms of governance as controls in idiosyncratic franchise dyads, Journal of Small Business Management, 46, 1, 50-72.

Combs J., D. Ketchen, 2003, Why do Firms Use Franchising as an Entrepreneurial Strategy? A Meta-Analysis, Journal of Management, 29, 443-465.

Combs J., D. Ketchen and V. Hoover, 2004, A strategic groups approach to the franchising- performance relationship, Journal of Business Venturing, 19, 877-897.

Crook R., D. Ketchen, J. Combs and S. Todd, 2008, Strategic resources and performance: A meta-analysis, Strategic Management Journal, 46, 1, 1141, 1154.

Croonen E., 2008, Trust and fairness in franchise relationships. In: George Hendrikse, Mika Tuunanen, Josef Windsperger und Gérard Cliquet (Eds): Strategy and governance of 
networks. Cooperatives, franchising, and strategic alliances. Heidelberg: Physica-Verlag, 183-203.

Cronbach L.J., 1951, Coeficiente alfa y la estructura interna de los test (Coefficient alpha and the internal structure of tests), Psychometrika 16, 3, 297-334.

Dant R.P., S.K. Weaven, B.L. Baker and H.J. Jeon, 2011, An introspective examination of single- unit versus multi-unit franchisees, Journal of the Academy of Marketing Science, 41, 4, 473-496.

Dant R, M. Grünhagen and J. Windsperger, 2011, Franchising Research Frontiers for the Twenty- First Century, Journal of Retailing, 87, 253-268.

Dant R.P. and G.T. Gundlach, 1998, The Challenge of Autonomy and Dependence in Franchised Channels of Distribution, Journal of Business Venturing, 14, 35-67.

Dant RP and N.I. Nasr, 1998, Control techniques and upward flow of information in franchising in distant markets: Conceptualization and preliminary evidence, Journal of Business Venturing, 31, 3-28.

Davidson R. and J. MacKinnon, 1993, Estimation and Inference in Econometrics, New-York, Oxford University Press.

Davies M, Lassar W, Manolis C, Prince M, Winsor R 2011, A model of trust and compliance in franchise relationships, Journal of Business Venturing 26(3), 321-340.

Dess G., and R. Robinson (1984) Measuring organizational performance in the absence of objective measures: The case of privately held firm and conglomerate business unit, Strategic Management Journal 5, 265-273.

Dickey M.H., D.H. McKnight and J.F. George, 2008, The role of trust in franchise organizations, International Journal of Organizational Analysis, 15, 3, 251-282.

Dyer J.H. and C.Wujin, 2000, The determinants of trust in supplier-automaker relationships in the U.S., Japan and Korea, Journal of International Business Studies 31, 2, 259-285.

Dyer, J.H. and H. Singh, 1998, The relational view: Cooperative strategy and sources of interorganizational competitive advantage, Academy of Management Review 23, 4, 660679.

Erramilli M.K., S. Agarwal, and C.S. Dev, 2002, Choice between non-equity entry modes: An organizational capability perspective, Journal of International Business Studies 33, 223-242.

Fama E.F. and M.C. Jensen, 1983, Separation of ownership and control, Journal of Law and Economics, 26, 301-325.

Fadairo M and C. Lanchimba, 2014, Organisational choices and performance in distribution systems, Applied Economics, 46, 14, 1609-1623. 
Garg V., A. Rasheed and R. Priem, 2005, Explaining franchisors'choices of organization forms within franchise systems, Strategic Organization, 3, 2, 185-217.

Gillis W., E. McEwan, T. Crook and S. Michael, 2011, Using tournaments to reduce agency problems: the case of franchising, Entrepreneurship Theory and Practice, 35, 3, 427-447.

Gibbons R., 2005, Four formalizable theories of the firm, Journal of Economic Behavior and Organization, 58, 200-245.

Glaister, K., and P. Buckley 1998, Measures of performance of UK international alliances, Organization Studies, 19(1), 89-118.

Gonzalez-Diaz M., V. Solis-Rodriguez, 2012, Why do entrepreneurs use franchising as a financial tool? an agency explanation, Journal of Business Venturing, 27, 3, 325-441.

Gomez R., I. Gonzalez and L. Vazquez, 2010, Multi-unit versus single-unit franchising: Assessing why franchisors use different ownership strategies, The Service Industries Journal, 30, 3, 463-476.

Gorovaia N. and J. Windsperger, 2013, Determinants of knowledge transfer strategy in franchising: Integrating knowledge-based and relational governance perspectives, The Service Industries Journal 33, 12, 1117-1134.

Griessmair M., D. Hussain and J. Windsperger, 2014, Trust and the tendency towards multi-unit franchising: A relational governance view, Journal of Business Reseearch, 67, 2337-2345.

Grünhagen M. and R. Mittelstaedt, 2002, Is bigger better?: The anticipation of scale efficiencies and decision participation as motivations for aspiring multi-unit franchisees, International Journal of Entrepreneurial Behaviour and Research, 8, 3, 188-200.

Grünhagen M. and R. Mittelstaedt, 2005, Entrepreneurs or Investors: Do Multi-unit Franchisees Have Different Philosophical Orientations?, Journal of Small Business Management, 43, 3, 207-225.

Gulati, R., J.A. Nickerson, 2008, Interorganizational trust, governance choice and exchange performance, Organization Science, 19, 5, 688-708

Hamilton L., 1991, How robust is robust regression? Stata Technical Bulletin, CollegeStation, TX: Stata Press., 2, 21- 26.

Hamilton B. and J. Nickerson, 2003, Correcting for endogeneity in stractegic management research, Strategic Organization, 1, 51-78.

Hart O.D., 1995, Firms Contracts and Financial Structures, Oxford University Press.

Hastie T. and R. Tibshirani, 1986, Generalized additive models, Statistical Science, 1, 297-318.

Heckman J., 1979, Sample selection bias as a specification error, Econometrica, 47, 153161. 
Heide J. and G. John, 1992, Do norms matter in marketing relationships? Journal of Marketing, 56, 2, 32-44.

Hamilton B., J. Nickerson, 2003, Correcting for Endogeneity, Strategic Management Research, Strategic Organization, 1, 51-78.

Hamilton L., 1991, How robust is robust regression? Stata Technical Bulletin, 2, 21-26, College Station, TX: Stata Press.

Hastie T. and R. Tibshirani, 1986, Generalized additive models (with discussion), Statistical Science, 1, 297-318.

Heckman J., 1979, Sample selection bias as a specification error, Econometrica, 47, 153-61.

Heide J., G. John, 1992, Do norms matter in marketing relationships? Journal of Marketing, $56,2,32-44$.

Hussain D., R. Perrigot, K. Mignonac, A. El Akremi, O. Herbach, 2013, Determinants of multi-unit franchising: An organizational economics framework, Managerial and Decision Economics, 34, 161-169.

Hussain D., J. Windsperger, 2013, A property rights view of multi-unit franchising, European Journal of Law and Economics, 35, 169-185.

Hussain D., J. Windsperger, 2015, Using organizational capability and transaction cost theory to explain multi-unit franchising, in Windsperger J, Cliquet G, Ehrmann T, Hendrikse G (Eds) Internfirm Networks: Franchising, Cooperatives and Strategic Alliances, Springer, Berlin, 35-55.

Jindal R., 2011, Reducing the size of internal hierarchy: the case of multi-unit franchising, Journal of Retailing, 87, 4, 549-562.

John, G., B.A. Weitz, 1988, Forward integration into distribution: an empirical test of transaction cost analysis, Journal of Law Economics and Organization, 4, 2, 337-355.

Kalnins A, F. Lafontaine, 2004, Multi-unit ownership in fast-food industry in Texas, RAND Journal of Economics, 35, 4, 747-761.

Kaufmann P., R. Dant, 1996, Multi-unit franchising: growth and management issues, Journal of Business Venturing, 11, 5, 343-358.

Kaufmann P.J., S.H. Kim, 1995, Master franchising and system growth rates, Journal of Marketing Channels, 4, 1, 49-64.

Koenker R. and G. Bassett, 1978, Regression Quantiles, Econometrica, 46, 1, 33-50.

Lafontaine F. and J.E. Oxley, 2004, International franchising practices in Mexico: do franchisors customize their contracts? Journal of Economics \& Management Strategy, $13,1,95-123$.

Macneil I.R., 1983, Values in contract: internal and external, Northwestern University Law Review, 78, 2, 340-369. 
Masten S. 1996, Empirical research in transaction cost economics: challenges, progress, directions, in transaction cost economics and beyond, J. Groenewegen (Ed.), Kluwer, Amsterdam.

Mathewson F. and R. Winter, 1985, The economics of franchise contracts, Journal of Law and Economics, 28, 503-526.

Mazzeo M.J., 2004, Retail contracting and organizational form: alternatives to chain affiliation in the motel industry, Journal of Economics \& Management Strategy, 13, 4, 599-615.

McKendall, M., and J. Wagner, 1997, Motive, opportunity, choice, and corporate illegality, Organization Science, 8, 6, 624-647.

Mumdziev N. and J. Windsperger, 2011, The structure of decision rights in franchising networks: a property rights perspective, Entrepreneurship Theory and Practice, $1042-2587$.

Mumdziev N. and J. Windsperger, 2013, An extended transaction cost model of decision rights allocation in franchising, Managerial and Decision Economics, 34, 170-182.

Podsakoff P.M., S.B. MacKenzie, J.Y. Lee and N.P. Podsakoff, 2003, Common method biases in behavioral research: a critical review of the literature and recommended remedies, Journal of Applied Psychology, 88, 879-903.

Poppo L. and T. Zenger, 2002, Do formal contracts and relational governance function as substitutes or complements? Strategic Management Journal, 23, 8, 707-725.

Rosenbaum P. and D. Rubin, 1983, The central role of the propensity score in observational studies for causal effects. Biometrika, 70, 1, 41- 55.

Rubin P., 1978, The theory of the firm and the structure of the franchise contract, Journal of Law and Economics, 21, 1, 223-233.

Rubin D., 1996, Multiple imputation after 18+ years, Journal of the American Statistical Association, 91, 473-489.

Sanchez-Gomez R., I. Suarez and L. Vazquez, 2010, Multi-unit versus single-unit franchising: assessing why franchisors use different ownership strategies, The Service Industries Journal, 30, 463-476.

Saussier S., A. Yvrande-Billon, 2004, Do Organization Choices Matter? Assessing the importance of governance through performance comparisons, in New Ideas in Contracting and Organizational Economics Research, James, H. S. (Ed.), Nova Science Publishers, New York.

Smith R. and R. Blundell, 1986, An Exogeneity Test for a Simultaneous Equation Tobit Model with an Application to Labor Supply, Econometrica, 54, 3, 679-685.

Sorenson O., J. Sorensen, 2001, Finding the right mix: Franchising, organizational learning and chain performance, Strategic Management Journal, 22, 713-724. 
Weaven S., L. Frazer, 2007, Expansion through multiple unit franchising: Australian franchisors reveal their motivations, International Small Business Journal, 25, 2, 173-205.

Weaven S., L. Frazer, 2004, Multiple Unit Franchising: Australian Revelations, International Society of Franchising Annual Conference.

Weaven S., L. Frazer, 2003, Predicting Multiple Unit Franchising: A Franchisor and Franchisee Perspective, Journal of Marketing Channels, 10, 53-82.

Williamson O., 1975, Markets and Hierarchies: Analysis and Antitrust Implications a Study in the Internal Organization, New York: Free Press.

Williamson O., 1985, The Economic Institution of Capitalism, New York.

Williamson O., 1991, Comparative economic organization: the analysis of discrete structural alternatives, Administrative Science, 36, 269-296.

Windsperger J. 2004a, The Dual Network Structure of Franchising Firms: Property Rights, Resource Scarcity and Transaction Cost Explanations: in Economics and Management of Franchising Networks, Windsperger J, Cliquet G, Hendrikse $\mathrm{G}$ and Tuunanen M., Eds., Heidelberg, 69-88.

Windsperger J., 2004b, Centralization of franchising networks: Evidence from the Austrian franchise sector, Journal of Business Research, 57 (12), 1361-1369

Windsperger J., 2013, Governance of franchising networks. In A. Grandori (Ed.), Handbook of Economic Organization: Integrating Economic and Organization Theory (pp. 522540). Cheltenham, UK: Edward Elgar Publishing.

Windsperger J., R. Dant, 2006, Contractibility and Ownership Redirection in Franchising: A Property Rights View, Journal of Retailing, 82, 3, 259-72.

Wood S., 2006, Generalized Additive Models: An Introduction with R, Chapman and Hall/CRC. Zellner RE, Dale DA, Brown LA (1980) Market Penetration and Locational Conflict in Franchise Systems, Decision Sciences, 11:58-90.

Zajac E.J., Olsen and P. Cyrus, 1993, From transaction cost to transactional value analysis: Implications for the study of interorganizational strategies, Journal of Management Studies 30, 1,131-145.

Zellner R., D. Dale and L. Brown, 1980, Market penetration and locational conflict in franchise systems, Decision sciences, 11, 58-90. 